\title{
Soft Tissue Sarcoma of the Head and Neck cM1 TNM Finding v8
}

National Cancer Institute

\section{Source}

National Cancer Institute. Soft Tissue Sarcoma of the Head and Neck cM1 TNM Finding v8. NCI Thesaurus. Code C136659.

Soft tissue sarcoma of the head and neck with distant metastasis. (from AJCC 8th Ed.) 